\title{
GAYA HIDUP HEDONIS DAN INTENSI KORUPSI PADA MAHASISWA PENGURUS LEMBAGA INTRA KAMPUS
}

\author{
Yuniar Dwi Sartika', Hudaniah ${ }^{2}$ \\ ${ }^{1,2}$ Fakultas Psikologi Universitas Muhammadiyah Malang \\ ${ }^{1}$ yuniardwisartika@gmail.com, ${ }^{2}$ hudaniah_hudaniah@yahoo.com
}

\begin{abstract}
Abstrak. Kasus korupsi banyak terjadi di lembaga pemerintahan sehingga intensi korupsi berpotensi terjadi di lembaga intra kampus yang merupakan miniatur dari lembaga pemerintahan. Intensi korupsi merupakan niat untuk melakukan korupsi. Banyak dijumpai individu memiliki gaya hidup hedonis, termasuk mahasiswa. Gaya hidup hedonis merupakan pola hidup yang mengutamakan kesenangan semata. Ketika individu tidak memiliki cukup uang untuk menunjang gaya hidup hedonisnya maka ia akan memiliki intensi korupsi. Tujuan penelitian ini untuk mengetahui adakah hubungan gaya hidup hedonis dan intensi korupsi. Penelitian ini merupakan penelitian kuantitatif korelasional dengan menggunakan teknik purposive sampling yang melibatkan 135 mahasiswa pengurus lembaga intra berusia 18-22 tahun. Pengambilan data menggunakan skala gaya hidup hedonis dan skala intensi korupsi yang dibuat sendiri oleh peneliti. Data yang didapatkan dianalisis menggunakan analisis product moment. Hasil penelitian menunjukkan adanya hubungan positif yang signifikan antara gaya hidup hedonis dengan intensi korupsi pada mahasiswa pengurus lembaga intra. Semakin tinggi gaya hidup hedonis mahasiswa, akan semakin tinggi pula intensi korupsinya.
\end{abstract}

Kata Kunci: Gaya hidup hedonis, intensi korupsi, mahasiswa pengurus lembaga intra

Abstract. Many corruption cases occurred in government institutions so that intention of corruption have the potential to occur in intra-campus institutions that are miniatures of government institutions. The intention of corruption is the intention to commit corruption. Many individuals are found to have hedonic lifestyles, including students. Hedonic lifestyle is a lifestyle that prioritizes pleasure. When an individual does not have enough money to support his hedonic lifestyle he will have a intention of corruption. The purpose of this research is to know whether there is any relationship of hedonic lifestyle and intention of corruption. This research is a correlational quantitative research using puposive sampling technique involving 135 students of intra institution aged 18-22 years. Data is retrieved using hedonic lifestyle scale and intention of corruption scale by researchers. The data obtained were analyzed using product moment analysis. The results showed a significant positive correlation between hedonic lifestyles with intention of corruption on students of intra institution. The highly of hedonic lifestyle of students, could be highly of their intention of corruption.

Keywords: Hedonic lifestyle, intention of corruption, student of intra institution 
Pada kenyataannya, korupsi tidak hanya terjadi di lingkungan politik, pemerintahan dan pengusaha saja namun bisa terjadi di lingkungan pendidikan terutama mahasiswa (Walida, 2015). Mahasiswa menilai perilaku korupsi yang dilakukan oleh pihak-pihak yang tidak memiliki keterlibatan dengan dirinya sebagai hal yang negatif, namun bila ada keterlibatan dengan dirinya, mereka akan cenderung menoleransi. Hal ini menunjukkan bahwa sebenarnya mahasiswa juga berpotensi melakukan perilaku korupsi, sebab meskipun tidak melakukan korupsi pada uang negara, akan tetapi mereka melakukan pelanggaran terhadap hal yang diamanahkan pada mereka (Falah, 2012).

Menurut Paramitha (2015), penyebab utama terjadinya korupsi pada lingkungan pendidikan adalah tidak adanya itikad untuk mewujudkan transparansi laporan keuangan. Bologna (Wahyuni, dkk, 2015) menambahkan penyebab utama korupsi karena tidak adanya sistem pengawasan yang ketat. Tindakan ini dapat dijadikan kesempatan untuk melakukan korupsi dengan melakukan penyelewengan dari anggaran pembelanjaan dengan melakukan manipulasi atau penggelapan. Berdasarkan hal tersebut, dapat diketahui bahwa korupsi tidak hanya terjadi pada satu instansi saja, melainkan pada seluruh instansi publik yang ada termasuk kampus sebagai lembaga pendidikan. Sehingga lembaga-lembaga mahasiswa yang berada di bawah naungan kampus sepeti lembaga intra juga berpotensi melakukan tindakan tersebut dikarenakan lembaga mahasiswa intra kampus merupakan miniature state atau student government yang melaksanakan tugas dan fungsi seperti sebuah negara. Aktivitas yang dilakukan lembaga kemahasiswaan intra kampus sebagai student government merupakan aktivitas politik (Sitepu, dalam Sandi, 2015).

Pada umumnya, dalam struktur lembaga kemahasiswaan terdapat pembagian kekuasaan sesuai dengan trias politica montesquieu. Pembagian kekuasaan tersebut terdiri atas badan eksekutif sebagai pelaksana pemerintahan (Badan Eksekutif Mahasiswa) yang berfungsi sebagai lembaga pelaksana kegiatan kemahasiswaan, badan legislatif (Senator) sebagai pembuat peraturan bersama eksekutif, dan badan yudikatif. Struktur tersebut serupa dengan struktur lembaga pemerintahan yang terdiri atas lembaga eksekutif yaitu presiden dan wakil presiden yang dibantu oleh para menteri, lembaga legislatif dan lembaga yudikatif yang masing-masing mempunyai fungsi sendiri dan satu sama lain saling berkaitan untuk mencapai tujuan pemerintahan negara (Tim Pansus Lokakarya REMA UPI, 2016).

Selain itu, sistem yang ada dalam lembaga pemerintahan sama halnya dengan sistem pada lembaga intra kampus. Hal ini dapat diketahui dari beberapa kesamaan diantara keduanya yakni baik lembaga pemerintahan maupun lembaga intra kampus memiliki sebuah struktur organisasi dimana terdapat pengurus dan anggota. Selain itu, lembaga pemerintahan mendapatkan sumber dana yang berasal dari Anggaran Pendapatan Belanja Negara (APBN) dimana penggunaan dana tersebut adalah untuk pelaksanaan program pembangunan negara sedangkan lembaga intra kampus mendapatkan sumber dana dari kampus dimana dana tersebut digunakan untuk kegiatan kemahasiswaan (Detik.com, Januari 2010). Untuk mendapatkan dana, baik lembaga pemerintahan maupun lembaga intra kampus memiliki kewajiban untuk mengajukan proposal kegiatan dan menyusun laporan pertanggung jawaban (LPJ) serta melakukan transparansi dana yang telah dikeluarkan tersebut (Okezone, Oktober 2016). 
Faktor pendorong perilaku korupsi di Indonesia sangat beragam. Salah satunya adalah gaya hidup bermewah-mewahan yang mengacu pada kesenangan material. Pernyataan tersebut sesuai dengan pendapat Jenier (2013), bahwa korupsi merupakan salah satu dampak yang diakibatkan dari gaya hidup hedonis. Hal ini dapat dibuktikan dengan adanya kasus korupsi yang dilakukan oleh GT. Perilaku korupsi GT tersebut didukung dari fasilitas yang didapatkan pada jabatannya. Diketahui bahkan dalam keadaan terdesak pun pegawai yang hanya berpangkat IIIA di Dirjen Pajak tersebut masih mempertahankan gaya hidup hedonisnya dengan memilih tinggal di hotel mewah di Singapura.

Menurut Japarianto (Umami, 2013), hedonisme adalah suatu konsep yang dimiliki seseorang berdasarkan kesenangan semata demi memenuhi kepuasan pikiran mereka sendiri. Hopkinson \& Pujari (Kirgiz, 2014) menyatakan bahwa kesenangan adalah keindahan tertinggi, dan gaya hidup hedonis bertujuan untuk mencari kesenangan. Aktivitas yang dilakukan oleh seseorang yang memiliki gaya hidup hedonis akan cenderung mengarah pada kebiasaan hidup glamor, menghamburkan-hamburkan uang, dan menghabiskan waktu untuk bersenang-senang (Wijaya, dalam Kusumastuti, 2006). Di Indonesia, saat ini sudah sering dijumpai bahwa setiap individu memiliki gaya hidup yang mengarah ke arah hedonisme. Hal ini ditunjukkan dengan banyaknya orang yang memilih model pakaian, tas dan barang-barang dengan merk terkenal, menggunakan handphone dengan fasilitas layanan terbaru, berbelanja di pusat perbelanjaan modern dan jalan-jalan untuk sekedar mengisi waktu luang.

Gaya hidup hedonis umumnya tidak hanya dimiliki oleh orang dewasa yang sudah bekerja saja, namun justru lebih banyak ditemukan di kalangan mahasiswa. Mahasiswa merupakan individu yang berada pada tahap pencarian jati diri sehingga mudah untuk dipengaruhi oleh adanya perubahan serta memiliki keinginan untuk mencoba hal-hal yang baru. Santrock (2008) menjelaskan bahwa masa remaja akhir berada pada rentang usia 18-22 tahun. Berdasarkan pernyataan tersebut, mahasiswa digolongkan sebagai remaja akhir yang menuju pada masa dewasa awal.

Masrukhi (dalam Ulfah, 2013) menyatakan bahwa 10\% mahasiswa merupakan mahasiswa idealis sedangkan 90\% merupakan mahasiswa hedonis. Berdasarkan pernyataan tersebut membuktikan bahwa pada saat ini perilaku hedonis semakin marak terjadi di kalangan mahasiswa. Berdasarkan survey yang dilakukan Nadzir (2015), diketahui bahwa kegiatan yang sering dilakukan mahasiswa adalah jalan-jalan ke mall (24\%), nongkrong di café (24\%), nonton ke bioskop (17\%), pergi ke toko buku (10\%), karaoke dengan teman-teman (9\%), belajar memahami materi dari dosen (7\%), bermain game (5\%) dan pergi ke perpustakaan hanya (3\%). Hal ini menunjukkan bahwa mahasiswa lebih mengutamakan kesenangan hidup daripada kegiatan belajar, karena waktu luang yang mereka miliki lebih banyak dihabiskan untuk bersenang-senang. Perilaku mahasiswa yang memiliki gaya hidup hedonis ini ditunjukkan dengan mencari kesenangan dengan berusaha untuk selalu tampil trendy, senang memiliki barang-barang mewah dengan merk yang prestisius, senang nongkrong di café atau mall dan makan makanan di restoran cepat saji (Susanto, dalam Dewi, 2013). Selain itu, mereka juga cenderung impulsif dan ikut-ikutan, senang menjadi pusat perhatian, dan menjadi lebih peka terhadap inovasi baru (Susianto, dalam Rianton, 2013). 
Mahasiswa memerlukan biaya yang tidak sedikit untuk memenuhi hasrat kesenangannya. Yusnia (Nadzir, 2015) menggambarkan bahwa gaya hidup hedonis memerlukan biaya yang tinggi, karena kebahagiaannya diukur dari material sehingga uang, harta, kekayaan, dan kemewahan hidup adalah norma yang mereka anut. Dengan uang, mereka dapat membeli segala kebutuhan seperti makanan, barang dengan merk tertentu, serta dapat memberikan segala bentuk kesenangan apapun (Moore \& Crips, dalam Weijers, 2012). Sumber pendapatan sebagian besar mahasiswa masih bergantung kepada orang tua, tentunya ketika ada keinginan yang tidak terpenuhi mereka akan merasa terancam dengan tuntutan perubahan gaya hidup yang selalu berubah tersebut. Mereka juga akan merasa gagal dan gelisah, serta merasa tertekan karena takut di cap ketinggalan zaman apabila tidak mengikuti trend (Rianton, 2013). Ketika gaya hidup menjadi sebuah kebutuhan akan citra diri yang bergengsi, maka keinginan mahasiswa untuk memenuhi kebutuhan hidupnya akan semakin meningkat. Dari sini, mahasiswa akan memaknai uang sebagai alat pemenuhan kebutuhan demi terpenuhinya segala sesuatu yang mereka inginkan.

Lebih dari setengah mahasiswa menganggap bahwa uang saku yang mereka dapatkan kurang, karena uang yang mereka keluarkan lebih banyak untuk kesenangan dibandingkan dengan kebutuhan mereka (Januarini, 2015). Sehingga banyak diantara mereka yang sering mengalami kehabisan uang sebelum akhir bulan. Hal ini mengakibatkan mahasiswa akan melakukan berbagai upaya untuk menghasilkan uang tambahan sekalipun dengan cara yang tidak jujur yakni dengan melakukan intensi korupsi.

Berdasarkan penelitian yang dilakukan Falah (2012) diketahui bahwa mahasiswa mengkorupsi uang dari orang tua yang digunakan untuk membayar kegiatan akademik seperti SPP dan sebagainya. Modus yang dilakukan mahasiswa adalah dengan menggunakan sisa uang pembayaran untuk kepentingan pribadi tanpa sepengetahuan orang tua. Mahasiswa juga meminta uang untuk biaya studi dengan jumlah yang melebihi kebutuhan aslinya. Selain mengkorupsi uang dari orang tua, mahasiswa juga melakukan tindakan korupsi terhadap uang beasiswa yang diamanahkan oleh pihak kampus kepada mereka untuk kepentingan pribadi. Dalam penelitian Zulkifli (2016), diketahui bahwa 16 mahasiswa di Kalimantan Timur yang mendapatkan beasiswa, 2 diantaranya menggunakan uang beasiswa untuk membiayai perkuliahannya sedangkan 14 mahasiswa lainnya menggunakan uang beasiswa untuk bersenang-senang dengan membeli pakaian trend dan up to date, membeli handphone dan tablet, makan-makan di café atau restoran, karaoke, nonton bioskop dan berbelanja di mall.

Mahasiswa pengurus lembaga intra kampus merupakan mahasiswa selayaknya pada umumnya. Mereka juga memiliki keinginan untuk bersenang-senang seperti mahasiswa lainnya. Keinginan-keinginan tersebut seperti berbelanja di pusat perbelanjaan modern dan membeli barang-barang bermerk untuk menunjang penampilan mereka. Hal ini dikarenakan mahasiswa pengurus lembaga intra kampus menjadi barometer bagi mahasiswa pada umumnya (Oley, 2012). Sehingga mereka dituntut menjadi panutan dengan memberikan kesan prestise bagi mahasiswa lain. Apabila mereka tidak memiliki cukup uang untuk menunjang kebutuhannya tersebut mereka akan berniat melakukan korupsi pada lembaga tempat mereka bernaung.

Dalam penelitian Puspitasari, et al (2015) yang membahas tentang pengelolaan keuangan pada lembaga kemahasiswaan intra di salah satu kampus juga diketahui bahwa 
mahasiswa pengurus UKM sering melebihkan anggaran dana kegiatan. Kelebihan dana tersebut tidak dikembalikan pada bendahara mahasiswa melainkan digunakan untuk kepentingan UKM itu sendiri dan juga kepentingan pribadi individu. Berdasarkan data dari staff biro kemahasiswaan salah satu perguruan tinggi di Malang yang diperoleh dari penelitian Rokhmah (2016), juga menyatakan bahwa beberapa mahasiswa yang terlibat dalam kegiatan organisasi kampus sering melakukan perilaku korupsi, semisal merancang anggaran kegiatan dengan tinggi, lalu menyalahgunakan sisa dana anggaran tersebut untuk kepentingan pribadi mereka. Perilaku korupsi lainnya adalah kegiatan fiktif atau memanipulasi proposal kegiatan yang pendanaannya telah dibiayai oleh pihak kemahasiswaan.

Dari empat penelitian tersebut dapat diketahui bahwa mahasiswa melakukan tindakan korupsi untuk kepentingan pribadi mereka. Sehingga untuk memenuhi keinginan pribadi mereka yang sifatnya mengacu pada kesenangan semata semisal untuk nongkrong di mall dengan kelompok teman sebayanya, makan-makanan di café terkenal, membeli barangbarang bermerk dan lain-lain mahasiswa pengurus lembaga intra memiliki suatu keinginan untuk melakukan perilaku korupsi. Hal ini merujuk pada pendapat Tanzi dan Treisman (Falah, 2012), bahwa perilaku korupsi diawali dengan adanya keinginan. Keinginan melakukan perilaku ini dilakukan dengan sengaja demi mencapai tujuan yang dimilikinya. Apabila perilaku ini dibiarkan begitu saja maka akan menimbulkan dampak yang buruk bagi mahasiswa khususnya yang menjadi pengurus lembaga intra di perguruan tinggi. Akibatnya adalah saat menjadi anggota organisasi yang besar misalnya dalam dunia politik, dikhawatirkan mereka juga akan melakukan perilaku korupsi bahkan pada uang negara.

Berdasarkan uraian di atas, masalah yang akan diangkat dalam penelitian ini adalah apakah ada Hubungan Gaya Hidup Hedonis dengan Intensi Korupsi pada Mahasiswa Pengurus Lembaga Intra. Sehingga tujuan dalam penelitian ini yaitu untuk mengetahui adakah hubungan gaya hidup hedonis dengan intensi korupsi pada mahasiswa pengurus lembaga intra. Manfaat yang bisa diambil dalam penelitian ini yaitu, pertama dapat memberikan sumbangan informasi bagi perkembangan psikologi, khususnya dalam bidang psikologi sosial yang membahas masalah gaya hidup hedonis dan intensi berperilaku korupsi di kalangan mahasiswa khususnya pengurus lembaga intra. Kedua, dapat memberikan pemahaman kepada mahasiswa tentang kaitan gaya hidup hedonis dengan intensi berperilaku korupsi sehingga hal ini dapat mencegah munculnya perilaku korupsi pada mahasiswa pengurus lembaga intra.

\section{METODE}

Penelitian ini menggunakan jenis metode penelitian kuantitatif korelasional yang bersifat non eksperimen, karena peneliti tidak memberikan perlakuan terhadap variabel penelitian melainkan hanya untuk mengetahui ada atau tidaknya hubungan antara dua variabel yang diteliti. Dua variabel yang diteliti dalam penelitian ini mengenai gaya hidup hedonis dan intensi korupsi pada mahasiswa pengurus lembaga intra.

Populasi yang akan digunakan dalam penelitian ini adalah mahasiswa yang menjadi pengurus lembaga intra. Alasan peneliti menggunakan mahasiswa pengurus lembaga intra karena menurut penelitian sebelumnya prevalensi gaya hidup hedonis pada mahasiswa tergolong tinggi dan intensi korupsi berpotensi dilakukan oleh mahasiswa 
yang menjadi pengurus di lembaga atau organisasi. Teknik pengambilan sampel yang digunakan adalah purposive sampling yaitu metode pengambilan sampel berdasarkan kriteria tertentu, yaitu siapa saja yang ditemui oleh peneliti dapat dijadikan sebagai sampel apabila orang tersebut sesuai dengan kriteria subyek penelitian yang telah ditentukan (Sugiyono, 2014). Subjek dalam penelitian ini adalah mahasiswa aktif yang memiliki rentang usia 18-22 tahun, mahasiswa tersebut menjadi pengurus di lembaga intra seperti halnya BEM (Badan Eksekutif Mahasiswa), SENAT Mahasiswa, HMJ (Himpunan Mahasiswa Jurusan), LSO (Lembaga Semi Otonom) dan UKM (Unit Kegiatan Mahasiswa) di Universitas Muhammadiyah Malang. Subjek yang mengisi skala secara langsung sebanyak 72 orang dan yang mengisi skala secara online sebanyak 63 orang. Lokasi pengambilan data bertempat di Student Center yang berada di GKB I, kampus III Universitas Muhammadiyah Malang dengan subjek penelitiannya adalah mahasiswa pengurus lembaga intra kampus.

Variabel bebas (X) dalam penelitian ini adalah gaya hidup hedonis. Gaya hidup hedonis adalah pola perilaku sebagai cara hidup seseorang bagaimana menghabiskan waktu dan uangnya untuk memperoleh kesenangan dan kenikmatan semata yang diwujudkan dengan suka menjadi pusat perhatian, menghabiskan waktu di luar rumah untuk bersenang-senang, dan menghabiskan uangnya untuk membeli barang-barang yang tidak diperlukan. Skala yang digunakan untuk mengukur gaya hidup hedonis didapatkan dari indikator oleh Nadzir (2015) berdasarkan tiga aspek menurut Well dan Tiger (Engel,1993; Rianton, 2013) yaitu aspek minat, aspek aktivitas dan aspek opini. Instrumen yang digunakan dalam penelitian ini disusun sendiri oleh peneliti sejumlah 24 item. Skala gaya hidup hedonis ini terdiri dari item favorable dan item unfavorable. Skala tersebut berbentuk likert yang terdiri dari 4 skor dimana respon yang diberikan subjek adalah STS (Sangat Tidak Sesuai); TS (Tidak Sesuai); S (Sesuai); dan SS (Sangat Sesuai). Berdasarkan uji validitas dan reliabilitas, dari 24 item setelah try out dan dianalisis diperoleh 18 item yang valid dan 6 item yang gugur. Skala gaya hidup hedonis yang digunakan dalam penelitian ini memiliki koefisien validitas berkisar antara 0,308 sampai 0,612 dan koefisien reliabilitas 0,883.

Variabel terikat (Y) dalam penelitian ini adalah intensi korupsi. Intensi korupsi adalah niat atau keinginan seseorang dalam menyalahgunakan kekuasaan dari suatu jabatan yang dimiliki untuk mendapatkan keuntungan pribadi. Skala yang digunakan untuk mengukur intensi korupsi disusun sendiri oleh peneliti berjumlah 58 item yang didapatkan dari indikator berdasarkan tiga aspek menurut Juliana (2014) yaitu aspek sikap terhadap perilaku korupsi, aspek norma subyektif terhadap perilaku korupsi dan persepsi terhadap kontrol perilaku korupsi. Skala intensi korupsi dalam penelitian ini terdiri atas item favorable dan item unfavorable yang masing-masing terdiri dari 4 alternatif jawaban yaitu SS (Sangat Sesuai) $=4$; S $($ Sesuai $)=3$; TS $($ Tidak Sesuai) $=2$; dan STS (Sangat Tidak Sesuai) $=1$ untuk item favorable dan STS (Sangat Tidak Sesuai) $=4 ;$ TS $($ Tidak Sesuai $)=3 ; \mathrm{S}$ (Sesuai) $=2$; dan SS $($ Sangat Sesuai $)=1$ untuk item unfavorable. Berdasarkan uji validitas dan reliabilitas, dari 58 item setelah try out dan dianalisis diperoleh 52 item valid dan 6 item gugur. Skala intensi korupsi yang digunakan dalam penelitian ini memiliki koefisien validitas berkisar antara 0,304 sampai 0,805 dan koefisien reliabilitas 0,951 .

Analisa data menggunakan uji korelasi product moment. Alasan menggunakan teknik korelasi product moment karena peneliti akan menguji hipotesis hubungan antara satu 
variabel bebas dengan satu variabel terikat yang mana dalam penelitian ini variabel bebas adalah gaya hidup hedonis dan variabel terikat adalah intensi korupsi. Analisa yang digunakan menggunakan aplikasi statistik SPSS (Statistical Packages for Social Science) versi 22.

\section{HASIL}

Subjek dalam penelitian ini adalah mahasiswa aktif yang menjadi pengurus inti lembaga intra di organisasi BEM (Badan Eksekutif Mahasiswa), SENAT Mahasiswa, HMJ (Himpunan Mahasiswa Jurusan), LSO (Lembaga Semi Otonom) dan UKM (Unit Kegiatan Mahasiswa) dengan rentang usia 18-22 tahun. Total subjek dalam penelitian ini adalah 135 orang. Berikut ini adalah penjelasan mengenai gambaran umum responden jika dilihat dari usia dan jenis kelamin.

Tabel 1. Gambaran umum responden berdasarkan usia dan jenis kelamin.

\begin{tabular}{lccc}
\hline \multicolumn{1}{c}{ Aspek Demografis } & Klasifikasi & Frekuensi & $(\mathbf{\%})$ \\
\hline Usia & 18 Tahun & 3 & $3 \%$ \\
& 19 Tahun & 14 & $10 \%$ \\
& 20 Tahun & 50 & $37 \%$ \\
& 21 Tahun & 43 & $32 \%$ \\
& 22 Tahun & 25 & $19 \%$ \\
\hline Total & & 135 & $100 \%$ \\
\hline Jenis Kelamin & Laki-laki & 58 & $43 \%$ \\
& Perempuan & 77 & $57 \%$ \\
\hline Total & & 135 & $100 \%$ \\
\hline Berdan
\end{tabular}

Berdasarkan tabel di atas, gambaran umum responden berdasarkan usia dan jenis kelamin dapat diketahui bahwa klasifikasi usia responden pada penelitian ini dibagi menjadi lima kelompok, dimana rentang usia dimulai pada usia 18 tahun hingga usia 22 tahun. Mayoritas subjek penelitian berusia 20 tahun sebesar 37\% dan minoritas berusia 18 tahun sebesar 3\% dari jumlah sampel penelitian yang ada. Sementara itu, apabila dilihat berdasarkan jenis kelamin, responden perempuan memiliki jumlah yang lebih banyak dengan proporsi sebesar $57 \%$ dan responden laki- laki memiliki proporsi yang lebih sedikit dengan proporsi $43 \%$.

Tabel 2. Gambaran umum responden berdasarkan organisasi dan jabatan

\begin{tabular}{lccc}
\hline \multicolumn{1}{c}{ Aspek Demografis } & Klasifikasi & Frekuensi & $\mathbf{( \% )}$ \\
\hline Organisasi & BEM & 18 & $13 \%$ \\
& SENAT & 17 & $13 \%$ \\
& HMJ & 35 & $15 \%$ \\
& LSO & 20 & $26 \%$ \\
& UKM & 45 & $33 \%$ \\
\hline Total & & 135 & $100 \%$ \\
\hline Jabatan & Ketua Umum & 32 & $24 \%$ \\
& Wakil Ketua & 7 & $5 \%$ \\
& Sekretaris Umum & 36 & $26 \%$ \\
& Bendahara Umum & 28 & $21 \%$ \\
& Ketua Divisi & 32 & $24 \%$ \\
\hline Total & & 135 & $100 \%$ \\
\hline
\end{tabular}


Apabila dilihat dari organisasi, responden yang mengisi kuesioner mayoritas mengikuti organisasi UKM sebanyak 33\% dan minoritas mengikuti organisasi BEM dan SENAT sebanyak $13 \%$. Kemudian peneliti membagi jabatan berdasarkan 5 kategori, dimana mayoritas responden menjabat sebagai sekretaris umum sebanyak $26 \%$ dan minoritas responden menjabat sebagai wakil ketua umum sebanyak $5 \%$.

Tabel 3. Gambaran umum responden berdasarkan uang saku per bulan dan jumlah pengeluaran dalam sebulan

\begin{tabular}{|c|c|c|c|}
\hline Aspek Demografis & Klasifikasi & Frekuensi & $(\%)$ \\
\hline \multirow{3}{*}{ Uang saku per bulan } & $<500.000$ & 13 & $10 \%$ \\
\hline & $500.000-1.000 .000$ & 55 & $41 \%$ \\
\hline & $>1.000 .000$ & 67 & $49 \%$ \\
\hline Total & & 135 & $100 \%$ \\
\hline \multirow{4}{*}{$\begin{array}{l}\text { Jumlah pengeluaran dalam sebulan } \\
\text { a. Kebutuhan pokok (makan, minum, } \\
\text { pakaian, dan lain-lain) }\end{array}$} & & & \\
\hline & $<500.000$ & 28 & $21 \%$ \\
\hline & $500.000-1.000 .000$ & 96 & $71 \%$ \\
\hline & $>1.000 .000$ & 11 & $8 \%$ \\
\hline \multicolumn{2}{|l|}{ Total } & 135 & $100 \%$ \\
\hline \multirow{3}{*}{$\begin{array}{l}\text { b. Kebutuhan sekunder (jalan-jalan, } \\
\text { nongkrong, dan lain-lain) }\end{array}$} & $<500.000$ & 59 & $44 \%$ \\
\hline & $500.000-1.000 .000$ & 74 & $55 \%$ \\
\hline & $>1.000 .000$ & 2 & $1 \%$ \\
\hline Total & & 135 & $100 \%$ \\
\hline \multicolumn{4}{|c|}{$\begin{array}{l}\text { Apabila dilihat dari jumlah uang saku per bulan dan jumlah pengeluaran dalam sebulan, } \\
\text { dapat dilihat bahwa mayoritas responden memiliki uang saku per bulan lebih dari Rp } \\
1.000 .000,- \text { sebanyak } 49 \% \text { dan minoritas responden memiliki uang saku per bulan } \\
\text { kurang dari Rp } 500.000,- \text { sebanyak } 10 \% \text {. Mayoritas jumlah pengeluaran responden untuk } \\
\text { kebutuhan pokok dalam sebulan berkisar Rp } 500.000 \text {,- hingga } 1.000 .000,- \text { dengan } \\
\text { proporsi sebanyak } 71 \% \text { dan minoritas pengeluaran dalam sebulan yaitu lebih dari Rp } \\
1.000 .000,- \text { dengan proporsi sebanyak } 8 \% \text {. Selain itu, jumlah pengeluaran responden } \\
\text { untuk kebutuhan sekunder lebih banyak berkisar Rp } 500.000 \text {,- hingga } 1.000 .000,- \\
\text { sebesar } 55 \% \text { dan minoritas lebih dari Rp } 1.000 .000 \text {,- dengan proporsi hanya } 1 \% \text {. }\end{array}$} \\
\hline \multicolumn{4}{|c|}{ Tabel 4. Gambaran umum responden berdasarkan kegiatan pada waktu luang. } \\
\hline Aspek Demografis & Klasifikasi & Frekuensi & $(\%)$ \\
\hline \multirow[t]{8}{*}{ Kegiatan pada waktu luang } & Menjalankan hobi & 29 & $22 \%$ \\
\hline & Istirahat & 26 & $19 \%$ \\
\hline & Menonton film & 23 & $17 \%$ \\
\hline & Bermain games & 3 & $2 \%$ \\
\hline & Nongkrong & 11 & $8 \%$ \\
\hline & Jalan-jalan & 14 & $11 \%$ \\
\hline & Membaca buku & 15 & $11 \%$ \\
\hline & Berorganisasi & 13 & $10 \%$ \\
\hline Total & & 135 & $100 \%$ \\
\hline
\end{tabular}


Apabila dilihat dari kegiatan pada waktu luang yang dilakukan responden, mayoritas responden lebih banyak menggunakan waktu luang mereka untuk menjalankan hobi mereka sebanyak $22 \%$ dan minoritas responden menggunakan waktu luang mereka untuk bermain games sebanyak $2 \%$.

Berdasarkan hasil perhitungan statistik dengan menggunakan teknik analisa product moment untuk mengetahui hubungan antara gaya hidup hedonis dan intensi korupsi, dapat dilihat dalam tabel berikut ini.

Tabel 5. Hubungan gaya hidup hedonis dengan intensi korupsi.

\begin{tabular}{lcccc}
\hline & \multicolumn{4}{c}{ Intensi Korupsi } \\
\cline { 2 - 5 } Gaya Hidup Hedonis & $\mathbf{F}$ & $\mathbf{P}$ & $\mathbf{r}$ & $\mathbf{r}^{\mathbf{2}}$ \\
& 135 & 0.000 & 0,338 & 0,114 \\
\hline
\end{tabular}

Berdasarkan tabel di atas, dapat diketahui bahwa nilai koefisien korelasi antara gaya hidup hedonis dan intensi korupsi adalah sebesar $\mathrm{r}=0,338(\mathrm{P}=0,000<0,05)$ dengan arah positif. Artinya, semakin tinggi skor gaya hidup hedonis, maka semakin tinggi pula skor intensi korupsi. Adanya hubungan gaya hidup hedonis dan intensi korupsi, maka hipotesis diterima, dengan kata lain terdapat hubungan yang signifikan antara gaya hidup hedonis dengan intensi korupsi pada mahasiswa pengurus lembaga intra. Dengan nilai koefisien korelasi sebesar 0,338 artinya keeretan hubungan antara gaya hidup hedonis dan intensi korupsi tergolong lemah. Sumbangan efektif gaya hidup hedonis dengan intensi korupsi dapat dilihat dari besar nilai koefisien determinasi yaitu $r^{2}=0,114$. Hal ini menunjukkan bahwa sumbangan efektif gaya hidup hedonis terhadap intensi korupsi pada mahasiswa pengurus lembaga intra adalah sebesar $11,4 \%$ dan $88,6 \%$ dipengaruhi oleh faktor lain.

Berdasarkan dari total subjek sebanyak 135 orang, dapat diketahui nilai rata-rata skor total gaya hidup hedonis responden adalah sebesar 38,51 dengan standar deviasi sebesar 5,447 . Adapun nilai minimum untuk skor total gaya hidup hedonis adalah sebesar 23 dan nilai maksimum adalah sebesar 52. Jika dilihat dari rentang skor gaya hidup hedonis maka responden paling banyak dalam kategori sedang sebesar $42 \%$ dan responden paling sedikit dalam kategori sangat rendah sebesar $2 \%$. Kategorisasi gaya hidup hedonis ini diperoleh dari rentangan skor dari penghitungan statistik. Hal ini dapat diartikan bahwa sebagian besar responden memiliki gaya hidup yang sedang. Penghitungan skor gaya hidup hedonis pada mahasiswa pengurus lembaga intra dapat dilihat pada tabel berikut.

Tabel 6. Penghitungan skor gaya hidup hedonis.

\begin{tabular}{cccc}
\hline Kategori & Rentangan Skor & F & ( \% ) \\
\hline Sangat Tinggi & $48-55$ & 4 & $3 \%$ \\
Tinggi & $42-47$ & 41 & $31 \%$ \\
Sedang & $35-41$ & 57 & $42 \%$ \\
Rendah & $28-34$ & 30 & $22 \%$ \\
Sangat Rendah & $22-27$ & 3 & $2 \%$ \\
\hline Total & & 135 & $100 \%$ \\
\hline
\end{tabular}


Selanjutnya untuk menganalisis data secara lebih spesifik, peneliti melakukan analisis tambahan dengan melihat gambaran umum gaya hidup hedonis responden jika ditinjau dari aspek demografis. Terdapat 5 aspek demografis yang diuji untuk mengetahui perbedaan gaya hidup hedonis yaitu jenis kelamin, usia, jabatan, uang saku per bulan dan jumlah pengeluaran dalam sebulan untuk kebutuhan pokok dan sekunder. Berdasarkan hasil analisis yang dilakukan dengan menggunakan uji ANOVA, diperoleh hasil yaitu gaya hidup hedonis tidak memiliki perbedaan jika ditinjau dari 4 aspek demografis yang meliputi jenis kelamin, usia, jabatan dan jumlah pengeluaran dalam sebulan untuk kebutuhan pokok dan sekunder. Namun, terdapat perbedaan jika gaya hidup hedonis ditinjau dari uang saku per bulan. Hal ini dapat dilihat dari nilai probabilitas yang dihasilkan lebih kecil dari 0,05 yaitu $(0,006<0,05)$ sehingga dapat disimpulkan bahwa ada perbedaan antara gaya hidup hedonis mahasiswa pengurus lembaga intra jika ditinjau dari uang saku per bulan yang dimiliki. Perbedaan gaya hidup hedonis jika ditinjau dari uang saku per bulan dapat dilihat dari tabel di bawah ini.

Tabel 7. Gambaran umum gaya hidup hedonis ditinjau dari uang saku per bulan.

\begin{tabular}{|c|c|c|c|c|c|c|c|c|}
\hline \multirow{2}{*}{$\begin{array}{l}\mathbf{G} \\
\mathbf{A}\end{array}$} & & \multirow{3}{*}{ Kategori } & \multicolumn{6}{|c|}{ Klasifikasi } \\
\hline & \multirow[b]{2}{*}{$\mathbf{H}$} & & \multicolumn{2}{|c|}{$<500.000$} & \multicolumn{2}{|c|}{$500.000-1.000 .000$} & \multicolumn{2}{|c|}{$>1.000 .000$} \\
\hline & & & $\mathrm{F}$ & $(\%)$ & $\mathrm{F}$ & $(\%)$ & $\mathrm{F}$ & $(\%)$ \\
\hline $\mathbf{A}$ & $\begin{array}{l}\mathbf{E} \\
\mathbf{D}\end{array}$ & Sangat Tinggi & 0 & $0 \%$ & 1 & $1,8 \%$ & 3 & $4,5 \%$ \\
\hline $\mathbf{H}$ & $\mathbf{O}$ & Tinggi & 4 & $30,8 \%$ & 12 & $21,8 \%$ & 25 & $37,3 \%$ \\
\hline $\mathbf{I}$ & $\mathbf{N}$ & Sedang & 5 & $38,4 \%$ & 26 & $47,3 \%$ & 26 & $38,8 \%$ \\
\hline D & I & Rendah & 3 & $23,1 \%$ & 14 & $25,5 \%$ & 13 & $19,4 \%$ \\
\hline $\begin{array}{l}\mathbf{U} \\
\mathbf{P}\end{array}$ & $\mathbf{S}$ & Sangat Rendah & 1 & $7,7 \%$ & 2 & $3,6 \%$ & 0 & $0 \%$ \\
\hline & & Total & 13 & $100 \%$ & 55 & $100 \%$ & 67 & $100 \%$ \\
\hline
\end{tabular}

Apabila dilihat dari persentase yang diperoleh, dapat diketahui bahwa responden yang memiliki uang saku per bulan lebih dari Rp 1.000.000,- dalam kategori gaya hidup hedonis yang sangat tinggi dengan persentase sebesar 4,5\%. Selain itu, responden yang memiliki uang saku per bulan lebih dari Rp 1.000.000,- juga tergolong memiliki gaya hidup yang tinggi sebesar 37,3\%. Responden yang memiliki uang saku per bulan berkisar Rp 500.000,- hingga 1.000.000,- termasuk dalam kategori gaya hidup yang sedang dengan persentase sebesar 47,3\% dan dalam kategori rendah sebesar 25,5\%. Sedangkan responden yang memiliki uang saku per bulan kurang dari Rp 500.000,- tergolong dalam kategori yang memiliki gaya hidup yang sangat rendah.

Dari penghitungan statistik, diperoleh nilai rata-rata skor total intensi korupsi responden adalah sebesar 103,87 dengan standar deviasi sebesar 13,030. Adapun nilai minimum untuk skor total intensi korupsi adalah sebesar 78 dan nilai maksimum adalah sebesar 128. Jika dilihat dari rentangan skor intensi korupsi maka responden mayoritas berada dalam kategori sedang sebesar $45 \%$ dan minoritas berada dalam kategori sangat tinggi sebesar 3\%. Skor intensi korupsi diperoleh berdasarkan rentangan skor dari penghitungan statistik. Sehingga hal ini dapat diartikan bahwa sebagian besar mahasiswa pengurus 
lembaga intra memiliki intensi korupsi sedang. Penghitungan skor intensi korupsi pada mahasiswa pengurus lembaga intra dapat dilihat pada tabel berikut.

Tabel 8. Penghitungan skor intensi korupsi

\begin{tabular}{cccc}
\hline Kategori & Rentangan Skor & F & $(\boldsymbol{\%})$ \\
\hline Sangat Tinggi & $127-143$ & 4 & $3 \%$ \\
Tinggi & $112-126$ & 39 & $29 \%$ \\
Sedang & $96-111$ & 61 & $45 \%$ \\
Rendah & $80-95$ & 25 & $19 \%$ \\
Sangat Rendah & $65-79$ & 6 & $4 \%$ \\
\hline Total & & 135 & $100 \%$ \\
\hline
\end{tabular}

Selanjutnya untuk menganalisis data secara lebih spesifik, peneliti melakukan analisis tambahan dengan melihat gambaran umum intensi korupsi responden jika ditinjau dari aspek demografis. Adapun 5 aspek demografis yang diuji untuk mengetahui perbedaan intensi korupsi meliputi jenis kelamin, usia, jabatan, uang saku per bulan dan jumlah pengeluaran dalam sebulan untuk kebutuhan pokok dan sekunder. Berdasarkan hasil analisis yang dilakukan dengan menggunakan uji ANOVA, diperoleh hasil yaitu intensi korupsi tidak memiliki perbedaan jika ditinjau dari 4 aspek demografis meliputi jenis kelamin, usia, uang saku per bulan dan jumlah pengeluaran dalam sebulan untuk kebutuhan pokok dan sekunder. Namun, terdapat perbedaan jika intensi korupsi ditinjau dari jabatan. Hal ini dapat dilihat dari nilai probabilitas yang dihasilkan lebih kecil dari 0,05 yaitu $0,044<0,05$ sehingga dapat disimpulkan bahwa terdapat perbedaan antara intensi korupsi mahasiswa pengurus lembaga intra jika ditinjau dari jabatan yang reponden miliki di organisasinya. Perbedaan intensi jika ditinjau dari jabatan dapat dilihat dari tabel berikut.

Tabel 9. Gambaran umum intensi korupsi ditinjau dari jabatan.

\begin{tabular}{|c|c|c|c|c|c|c|c|c|c|c|c|}
\hline \multirow{9}{*}{$\begin{array}{ll}\text { I } & K \\
\text { N } & O \\
\text { T } & R \\
\text { E } & U \\
N & P \\
S & S \\
I & I\end{array}$} & \multirow{3}{*}{ Kategori } & \multicolumn{10}{|c|}{ Klasifikasi } \\
\hline & & \multicolumn{2}{|c|}{ Ketua } & \multicolumn{2}{|c|}{ Wakil } & \multicolumn{2}{|c|}{ Sekretaris } & \multicolumn{2}{|c|}{ Bendahara } & \multicolumn{2}{|c|}{$\begin{array}{l}\text { Ketua } \\
\text { Divisi }\end{array}$} \\
\hline & & $\mathrm{F}$ & $(\%)$ & $\mathrm{F}$ & $(\%)$ & $\mathrm{F}$ & $(\%)$ & $\mathrm{F}$ & $(\%)$ & F & $(\%)$ \\
\hline & $\begin{array}{l}\text { Sangat } \\
\text { Tinggi }\end{array}$ & 0 & $0 \%$ & 0 & $0 \%$ & 1 & $3 \%$ & 0 & $0 \%$ & 3 & $9 \%$ \\
\hline & Tinggi & 12 & $37 \%$ & 2 & $28 \%$ & 7 & $19 \%$ & 7 & $25 \%$ & 12 & $37 \%$ \\
\hline & Sedang & 13 & $41 \%$ & 3 & $43 \%$ & 21 & $58 \%$ & 11 & $39 \%$ & 13 & $41 \%$ \\
\hline & Rendah & 7 & $22 \%$ & 2 & $29 \%$ & 6 & $17 \%$ & 5 & $18 \%$ & 5 & $13 \%$ \\
\hline & $\begin{array}{l}\text { Sangat } \\
\text { Rendah }\end{array}$ & 0 & $0 \%$ & 0 & $0 \%$ & 1 & $3 \%$ & 5 & $18 \%$ & 0 & $0 \%$ \\
\hline & Total & 32 & $100 \%$ & 7 & $100 \%$ & 36 & $100 \%$ & 28 & $100 \%$ & 32 & 100 \\
\hline
\end{tabular}

Apabila dilihat dari persentase yang diperoleh, dapat diketahui bahwa jabatan ketua divisi memiliki intensi korupsi tergolong sangat tinggi sebesar 9\%, jabatan ketua tergolong tinggi sebesar 37\%, jabatan sekretaris tergolong sedang sedang sebesar 58\% jabatan wakil tergolong rendah sebesar $29 \%$ dan jabatan bendahara memiliki intensi tergolong sangat rendah sebesar $18 \%$. 
Tabel 10. Gambaran umum intensi korupsi berdasarkan indikator gaya hidup hedonis.

\begin{tabular}{cccccc}
\hline & Indikator Gaya Hidup Hedonis & $\mathbf{P}$ & $\mathbf{P}$ & $\mathbf{r}$ & $\mathbf{r}^{\mathbf{2}}$ \\
\cline { 2 - 6 } Intensi & Cenderung impulsif & 0,678 & & & \\
Korupsi & Kurang rasional & 0,001 & & & \\
& Suka mencari perhatian & 0,933 & 0,002 & 0,385 & 0,148 \\
& Senang pergi ke tempat santai & 0,785 & & & \\
& Cenderung follower & 0,290 & & & \\
\hline
\end{tabular}

Berdasarkan hasil analisis yang dilakukan dari 6 indikator gaya hidup hedonis yang diuji dengan intensi korupsi, diketahui bahwa seluruh indikator gaya hidup hedonis berpengaruh terhadap intensi korupsi. Hal ini dapat dilihat dari nilai probabilitas yang diperoleh yaitu sebesar $(P=0,002<0,05)$. Dari tabel di atas juga dapat diketahui bahwa kurang rasional memiliki nilai probabilitas paling tinggi diantara indikator yang lain sehingga dapat disimpulkan bahwa kurang rasional merupakan indikator yang paling berpengaruh terhadap intensi korupsi. Besar nilai koefisien indikator gaya hidup hedonis hedonis terhadap intensi korupsi adalah sebesar 0,385 dan sumbangan efektif yang diberikan indikator gaya hidup hedonis terhadap intensi korupsi adalah sebesar 14,8\%.

\section{DISKUSI}

Hasil dari penelitian yang telah dilakukan, membuktikan bahwa adanya hubungan positif yang signifikan antara gaya hidup hedonis dengan intensi korupsi pada mahasiswa pengurus lembaga intra, dengan nilai koefisien korelasi sebesar $(\mathrm{r}=0,338, \mathrm{P}=0,000<$ 0,05). Dari hasil tersebut menunjukkan bahwa hipotesis dalam penelitian ini diterima. Hubungan positif diantara kedua variabel dalam penelitian ini menunjukkan adanya hubungan yang searah, artinya semakin besar keinginan mahasiswa pengurus lembaga intra untuk bersenang-senang dengan menghabiskan waktu untuk nongkrong, senang berbelanja di mall, membeli barang-barang mewah dan bermerk, maka keinginan untuk menggunakan jabatannya di lembaga untuk mendapatkan keuntungan pribadi semakin besar pula, begitu juga sebaliknya. Hal ini didukung oleh Tanzi \& Treisman (Falah, 2012) bahwa perilaku korupsi diawali dengan adanya keinginan. Keinginan untuk melakukan perilaku korupsi akan menjadi kuat apabila individu menilai perilaku tersebut positif, ketika mereka mendapatkan dorongan sosial untuk mewujudkannya, dan ketika mereka percaya bahwa mereka memiliki tujuan dan kesempatan untuk melakukan perilaku korupsi (Ajzen dalam Rosdiana 2011). Banyak studi yang menyimpulkan bahwa faktor dalam diri individu memberikan kontribusi terjadinya perilaku korupsi (Rabl, 2011).

Besar koefisien korelasi antara gaya hidup hedonis dengan intensi korupsi pada mahasiswa pengurus lembaga intra adalah sebesar 0,338, artinya keeratan hubungan antara kedua variabel tergolong lemah. Menurut Sugiyono (2014), hal ini menunjukkan bahwa gaya hidup hedonis memiliki kontribusi yang rendah terhadap intensi korupsi. Sumbangan efektif yang diberikan gaya hidup hedonis terhadap intensi korupsi adalah sebesar 11,4\%. Hasil tersebut menunjukkan bahwa sebanyak 88,6\% intensi korupsi dipengaruhi oleh faktor lain yang memiliki kontribusi lebih tinggi dibandingkan dengan 
gaya hidup hedonis. Adapun faktor lain yang mempengaruhi intensi korupsi adalah kebermaknaan hidup (Juliana, 2014), norma subyektif dan durasi keanggotaan (Agustiani, 2015).

Dalam penelitian Juliana (2014) mengungkapkan bahwa kebermaknaan hidup memiliki kontribusi terhadap intensi korupsi sebesar 17,2\%. Penelitian ini menunjukkan bahwa adanya evaluasi positif terhadap makna hidup dapat membuat kegiatan-kegiatan yang dilakukan lebih terarah dan lebih disadari, serta akan mampu menyesuaikan diri dengan lingkungannya meskipun ada aturan-aturan yang membatasi. Ketika berada dalam situasi yang memiliki kesempatan untuk melakukan korupsi, seseorang yang memiliki kebermaknaan hidup akan dapat menentukan sendiri apa yang yang baik untuk dilakukan. Sikap yang positif terhadap pekerjaan akan tercipta jika seseorang telah menemukan kebermaknaan pada hidup dalam pekerjaannya. Individu tersebut akan melakukan pekerjaannya dengan sungguh-sungguh sehingga ia akan memanfaatkan secara maksimal seluruh potensi yang dimiliki dan akan tercipta rasa kecintaan pada diri individu tersebut terhadap pekerjaannya, sehingga tidak ada dorongan untuk melakukan korupsi. Individu akan mampu menahan dirinya untuk lebih memilih melaksanakan kewajibannya dengan penuh komitmen, bertanggung jawab, memprioritaskan cara, sikap dan hasil kerja serta lebih mengutamakan kepentingan umum daripada kepentingan dirinya sendiri.

Selain itu, dalam penelitian Agustiani (2015) mengungkapkan bahwa norma subjektif dan durasi keanggotaan memiliki keterkaitan dengan intensi korupsi sebesar 26,6\%. Norma subjektif merupakan tekanan yang dirasakan anggota dari kelompok untuk mengikuti norma yang ada dalam suatu kelompok. Perilaku anggota dalam suatu kelompok dipengaruhi oleh norma yang terdapat dalam kelompok tersebut. Norma yang mendukung adanya intensi korupsi akan membentuk intensi korupsi. Selama menjadi anggota dalam suatu organisasi atau lembaga, semakin lama durasi kenggotaannya, maka antar anggota akan mengikuti nilai dan norma dalam organisasi atau lembaga tersebut. Durasi kenggotaan yang panjang akan membuat anggota terbiasa dengan pola pikir dan keyakinan pada organisasi tersebut, sehingga apabila norma kelompok mendukung intensi korupsi, maka semakin lama durasi kenggotaan seseorang, akan semakin tinggi intensi korupsinya.

Berdasarkan hasil penelitian ini dapat diketahui bahwa gaya hidup hedonis mahasiswa pengurus lembaga intra memiliki peran terhadap intensi korupsi. Hal ini sesuai dengan faktor internal yang menyebabkan individu melakukan perilaku korupsi diantaranya adalah ketamakan yang berupa sifat keserakahan dimana individu tidak mau menerima dan mensyukuri atas apa yang sudah didapatkan serta perilaku konsumtif yang berlebihan tanpa memperhatikan manfaat dan kerugiannya (Dwiputrianti, dalam Walida, 2015). Hal tersebut juga didukung oleh Arifin (Agustiani, 2015), yang menyatakan bahwa faktor penyebab korupsi adalah adanya keinginan yang berawal dari dorongan yang membuat individu memunculkan intensi korupsi.

Selain faktor internal, perilaku korupsi juga dipengaruhi oleh faktor eksternal diantaranya terdiri dari aspek organisasi yaitu norma yang berlaku dalam suatu kelompok. Apabila norma dalam suatu kelompok tersebut mendukung intensi korupsi, maka besar kemungkinan anggota organisasi akan memiliki intensi korupsi yang tinggi. Faktor lainnya adalah dari aspek lingkungan tempat individu tinggal dan organisasi berada. 
Apabila individu dan organisasi berada dalam lingkungan dengan intensi korupsi tinggi, maka individu tersebut akan terbawa oleh norma dan memiliki intensi yang tinggi pula. Hal ini sesuai dengan Fishbein \& Ajzen (1975) bahwa intensi tidak hanya berasal dari diri pribadi melainkan juga dari pengaruh sosial dan persepsi terhadap kontrol perilaku. Sikap terhadap perilaku dibentuk oleh pengalaman langsung atau tidak langsung dengan perilaku tersebut, kemudian hal ini dapat mengubah keyakinan mengenai konsekuensi terhadap perilaku yang akan ditampilkan. Selain itu, individu juga akan membentuk penilaian terhadap konsekuensi menampilkan perilaku tersebut (Semin dan Fiedler, dalam Juliana 2014).

Mahasiswa pengurus lembaga intra dalam penelitian ini memiliki gaya hidup hedonis dalam kategori yang sedang dengan proporsi sebesar 57\%. Hal ini berarti mahasiswa pengurus lembaga intra dalam melakukan aktivitasnya, mengungkapkan minat dan mengungkapkan opininya yang berkaitan dengan gaya hidup hedonis mengarah pada kategori tinggi maupun rendah (Dewi, 2013). Pada umumnya, mahasiswa pengurus lembaga intra kampus sama halnya dengan mahasiswa lainnya yang masih tergolong remaja akhir dimana pada masa ini mahasiswa memiliki emosi yang labil sehingga mudah terpengaruh pada lingkungan di sekitarnya. Oleh sebab itu, mereka memiliki keinginan supaya penampilan, gaya, tingkah laku serta cara bersikap dapat menarik perhatian orang lain yang terutama perhatian pada kelompok sebayanya (Monks, et al, 2002). Hal tersebut dilakukan supaya dapat merasa senang, aman, dan merasa berharga apabila dirinya diterima dan memperoleh tempat di dalam suatu kelompok tersebut. Sebaliknya, apabila remaja tidak diterima atau bahkan diasingkan oleh kelompok teman sebayanya, maka mereka akan merasa menderita dan tidak berharga (Ali \& Asrori, dalam Ulfah, 2015).

Dari hasil penelitian yang didapatkan menunjukkan tidak ada perbedaan gaya hidup hedonis pada mahasiswa pengurus lembaga intra jika ditinjau dari jenis kelamin. Hal ini didukung oleh penelitian Setyaningsih (2013) yang menunjukkan bahwa tidak terdapat perbedaan perilaku konsumtif berdasarkan jenis kelamin baik laki-laki maupun perempuan. Menurut Wagner (Setyaningsih, 2013), mahasiswa menganggap uang saku yang dimiliki bukan dari penghasilan sendiri sehingga laki-laki akan bersikap mengikuti trend yang ada dengan menjaga penampilannya seperti berdandan, melakukan perawatan rambut, wajah dan tubuh. Begitu halnya dengan perempuan yang selalu memperhatikan penampilan dan merawat penampilannya dengan membelanjakan uang untuk pakaian, aksesoris, dan sepatu (Rosandi, 2004).

Berdasarkan hasil dari penelitian menunjukkan bahwa uang saku per bulan yang dimiliki responden memiliki hubungan dengan gaya hidup hedonis. Hasil dalam penelitian menunjukkan bahwa responden yang memiliki uang saku per bulan lebih besar dari Rp 1.000.000,- cenderung memiliki keinginan untuk bersenang-senang lebih tinggi dibandingkan dengan responden yang memiliki uang saku per bulan kurang dari Rp 500.000,-. Hasil tersebut sesuai dengan penelitian yang dilakukan oleh Purworini (2003) yang menunjukkan bahwa semakin tinggi uang saku yang dimiliki semakin tinggi pula gaya hidup hedonis. Selain itu, Setyaningsih (2013) juga menyatakan bahwa semakin banyak uang yang dimiliki oleh seseorang, maka semakin sering seseorang tersebut ingin membelanjakan uangnya untuk mendapatkan segala sesuatu yang dilihatnya. 
Beberapa faktor yang menyebabkan mahasiswa berperilaku hedonis yaitu adanya keinginan membeli barang bukan karena membutuhkan melainkan karena memberikan kepuasan tersendiri bagi mereka serta adanya keinginan untuk mempertahankan eksistensi di lingkungannya. Selain itu, mahasiswa juga cenderung menirukan budaya baru dengan mengikuti perkembangan trend mode yang berkembang di masyarakat melalui televisi, majalah fashion, jejaring sosial serta kecanggihan teknologi yang lainnya. Menurut Susanto (Trimartati, 2014), mahasiswa yang memiliki kecenderungan gaya hidup hedonis, biasanya akan berusaha agar sesuai dengan status sosial, melalui gaya hidup yang tercermin dengan simbol-simbol tertentu, seperti merk yang digunakan dalam kehidupan sehari-hari dan segala sesuatu yang berhubungan serta dapat menunjukkan tingkat status sosial yang tinggi. Hal inilah yang menyebabkan mahasiswa memerlukan uang yang tidak sedikit. Januarini (2015) menyatakan bahwa lebih dari setengah mahasiswa menganggap uang saku yang mereka dapatkan kurang sehingga kebanyakan mahasiswa dalam penggunaan uang saku sering habis dan meminta uang saku tambahan dengan berbagai macam alasan. Hal ini mengakibatkan mahasiswa akan melakukan berbagai upaya untuk menghasilkan uang tambahan sekalipun dengan cara yang tidak jujur yakni dengan melakukan intensi korupsi (Jenier, 2013).

Berdasarkan hasil penelitian, dapat dilihat bahwa indikator gaya hidup hedonis memiliki pengaruh terhadap munculnya intensi korupsi pada mahasiswa pengurus lembaga intra. Indikator gaya hidup dalam penelitian ini meliputi cenderung impulsif, suka mencari perhatian, kurang rasional, senang pergi ke tempat santai, cenderung follower dan mudah dipengaruhi. Hal ini didukung oleh Graaf \& Huberts (2008) bahwa motif seseorang dalam melakukan korupsi tidak hanya untuk memperoleh keuntungan secara materi, tapi juga agar bisa meningkatkan hubungan pertemanan, percintaan, status, dan pencitraan serta membuat orang lain menjadi terkesan, terpesona dan mudah terpengaruh. Dalam penelitian ini juga diperoleh hasil bahwa kurang rasional merupakan indikator yang paling berpengaruh terhadap intensi korupsi. Hal ini didukung oleh Earliyanto (Artaningtyas, 2015) bahwa seseorang yang konsumtif akan menimbulkan pemborosan dan menyebabkan adanya kecemburuan sosial, karena individu akan membeli semua barang yang diinginkan tanpa memikirkan harga barang tersebut murah atau mahal, apakah barang tersebut diperlukan atau tidak, sehingga cenderung tidak memikirkan kebutuhan yang akan datang, membelanjakan uang pada saat sekarang tanpa berfikir kebutuhan di masa mendatang. Pembelian berlebihan atau boros ini membawa dampak negatif yaitu memandang harta secara salah dan menjadikan harta sebagai tujuan hidup sehingga menyebabkan individu melakukan segala hal untuk memperoleh harta, mulai dari bekerja yang berlebihan sampai menggunakan cara yang instan seperti korupsi, mencuri dan sebagainya (Aryanto, 2007).

Pernyataan di atas, menunjukkan bahwa korupsi yang dilakukan adalah bertujuan untuk memenuhi gaya hidup hedonis, sebab Susianto (Rianton, 2013) menyatakan bahwa seseorang yang memiliki gaya hidup hedonis cenderung impulsif, senang menjadi pusat perhatian, cenderung follower, dan peka terhadap inovasi baru. Suwindo (2001) menambahkan bahwa karakteristik seseorang bergaya hidup hedonis adalah kurang rasioanl dan mudah dipengaruhi. Dari pernyataan di atas juga menunjukkan mahasiswa pengurus lembaga intra memiliki intensi korupsi supaya dapat meningkatkan pencitraan untuk membuat orang lain di sekitarnya terkesan. Hal ini dikarenakan mahasiswa 
pengurus lembaga intra merupakan barometer bagi mahasiswa lainnya sehingga mereka dituntut untuk memberikan kesan yang baik (Oley, 2012).

Berdasarkan hasil penelitian ini menunjukkan bahwa intensi korupsi jika ditinjau dari jabatannya memiliki perbedaan. Mahasiswa yang memiliki intensi korupsi paling tinggi adalah yang menjabat sebagai ketua divisi. Namun dari hasil penelitian, membuktikan bahwa masing-masing jabatan berpeluang untuk memiliki intensi korupsi. Hal ini didukung bagi sebagian orang yang beranggapan bahwa korupsi merupakan perilaku merugikan, namun bagi sebagian orang yang lain beranggapan bahwa korupsi itu sangat menguntungkan, sehingga korupsi terus dilakukan karena korupsi dianggap menguntungkan, maka banyak orang yang senang menikmati ketika mereka korupsi, bahkan korupsi dengan mudah dapat dibagi-bagikan kepada banyak orang meskipun tidak merata (Elliot, 2011). Selain itu, perilaku korupsi merupakan perbuatan yang dilakukan oleh setiap orang yang dengan tujuan menguntungkan diri sendiri atau orang lain atau suatu korporasi, menyalahgunakan kewenangan, kesempatan atau sarana yang ada padanya karena jabatan atau kedudukan yang dapat merugikan keuangan negara atau perekonomian Negara (Muljanto, dalam Graydison \& Budiana, 2013). Dari pengertian ini, dapat menunjukkan bahwa semua jabatan berpotensi memiliki intensi korupsi dikarenakan mahasiswa pengurus lembaga intra selain memiliki tujuan untuk menguntungkan diri sendiri mereka juga memiliki tujuan untuk memberikan keuntungan pada suatu korporasi atau untuk memperlancar kegiatan yang mereka lakukan.

Kelebihan dalam penelitian ini adalah belum adanya penelitian sebelumnya yang meneliti tentang hubungan gaya hidup hedonis dengan intensi korupsi pada mahasiswa pengurus lembaga intra. Selain itu, penelitian ini dapat memberikan sumbangan informasi terkait gambaran hubungan gaya hidup hedonis dengan intensi korupsi. Keterbatasan dalam penelitian ini adalah dengan menggunakan metode pengumpulan data hanya berupa kuesioner. Meskipun kuesioner dianggap sebagai cara yang paling efisien dalam pengumpulan data dalam jumlah besar, namun lebih sulit untuk mendeteksi ketidakjujuran responden dalam menjawab, kesalahpahaman terhadap isi kalimat dan ketidaktelitian dalam pengisian kuesioner. Oleh sebab itu, untuk memperkuat hasil penelitian diperlukan metode lain yaitu misalnya dengan menggunakan metode kualitatif dengan melakukan observasi dan wawancara secara langsung dengan responden.

\section{SIMPULAN DAN IMPLIKASI}

Berdasarkan hasil penelitian yang telah diperoleh, dapat diketahui bahwa terdapat hubungan yang signifikan antara gaya hidup hedonis dengan intensi korupsi pada mahasiswa pengurus lembaga intra. Artinya, semakin tinggi skor gaya hidup hedonis, maka semakin tinggi pula skor intensi korupsi. Sumbangan efektif gaya hidup hedonis terhadap intensi korupsi pada mahasiswa pengurus lembaga intra adalah sebesar $11,4 \%$ dan $88,6 \%$ dipengaruhi oleh faktor lain.

Implikasi dari penelitian ini yaitu peran diri sendiri sangat penting dalam menyaring budaya pada perkembangan zaman saat ini. Mahasiswa pengurus lembaga intra disarankan supaya membangun kontrol diri dan konsep diri yang kuat agar tidak terpengaruh dengan budaya dan lingkungan yang mendorong terjadinya perilaku hedonis, kritis dalam bertindak supaya mampu mengkaji dan mengambil keputusan secara tepat 
dalam menghadapi masalah dan tidak memandang rendah diri sendiri. Kepada orang tua disarankan supaya memberikan pengarahan dan informasi mengenai perkembangan zaman, membentuk pola pengasuhan yang demokratif, memberikan bimbingan dalam menanam nilai-nilai moral dan perilaku antikorupsi pada anak. Selanjutnya bagi pihak kampus disarankan untuk memberikan pembinaan antikorupsi dan memperketat sistem manajemen yang berlaku dalam kampus supaya terwujudnya transparansi anggaran. Bagi peneliti selanjutnya disarankan untuk melakukan penelitian terkait gaya hidup hedonis dan intensi korupsi ditinjau dari pola asuh, peer pressure, dan variabel psikologis lainnya serta menggunakan metode kualitatif untuk mendapatkan data yang lebih mendalam mengenai gaya hidup hedonis dengan intensi korupsi.

\section{REFERENSI}

Agustiani, R.A. (2015). Intensi Korupsi ditinjau dari norma subjektif dan durasi keanggotaan pada aktivis partai politik GK, GR, serta PI di Kabupaten Tegal. Skripsi. Semarang: Fakultas Psikologi Universitas Islam Sultan Agung Semarang.

Artaningtyas, R.M. (2015). Hubungan antara konsep diri dengan perilaku konsumtif pada mahasiswi Universitas Muhammadiyah Surakarta. Skripsi. Surakarta: Fakultas Psikologi Universitas Muhammadiyah Surakarta.

Aryanto, A. (2007). Hubungan antar konsep diri dan konformitas kelompok dengan perilaku konsumtif pada remaja puri. Skripsi. Surakarta: Fakultas Psikologi Universitas Muhammadiyah Surakarta.

Dewi, S.K. (2013). Hubungan antara kepercayaan diri dengan kecenderungan gaya hidup hedonis pada mahasiswi di Surakarta. Naskah Publikasi. Surakarta: Fakultas Psikologi Universitas Muhammadiyah Surakarta.

Dewi. (2016, February 25 th). Kerugian negara akibat korupsi 2015 sebesar 3,1 triliun. Retrieved January 22, 2017, from http://www.antikorupsi.org/id/content/kerugian-negara-akibat-korupsi-2015sebesar-31-triliun.

Elliot, K.A. (2011). Korupsi dan ekonomi dunia. Jakarta: Yayasan Obor Indonesia.

Falah, F. (2012). Perilaku korupsi di mata mahasiswa. Semarang: Fakultas Psikologi Universitas Islam Sultan Agung Semarang.

Fishbein, M., \& Ajzen, I. ( 1975 ). Belief, attitude, intentions and behavior: an introduction to theory and research. California: Addison-Wesley Publishing Company, Inc.

Graydison, B.A., \& Budiana, M.S. (2013). Dampak perilaku korupsi ditinjau dari stres pada keluarga di Kabupaten Lombok Timur Selong - Nusa Tenggara Barat (NTB). Skripsi. Surabaya: Fakultas Ilmu Pendidikan Universitas Negeri Surabaya. 
Januarini, S. (2015). Pengaruh gaya hidup hedonis terhadap perilaku konsumtif mahasiswa. Skripsi. Malang: Fakultas Psikologi Universitas Muhammadiyah Malang.

Jenier, C. (2013). Ilmu sosial budaya dasar (Kebudayaan sebagai syarat dan ancaman). Malang: Fakultas Perikanan dan Ilmu Kelautan Universitas Brawijaya Malang.

Juliana, F. (2014). Hubungan antara kebermaknaan hidup dengan intensi korupsi pada pegawai negeri sipil di wilayah kecamatan Colomadu Karanganyar. Skripsi. Surakarta: Program Studi Psikologi Fakultas Kedokteran Universitas Sebelas Maret Surakarta.

Kirgiz, A. (2014). Hedonism, a consumer disease of the modern age: gender and hedonic shopping in Turkey. Global Media Journal, 4(8).

Kusumastuti, A. (2006). Hubungan antara konsep diri dan konformitas dengan kecenderungan gaya hidup hedonis paa remaja. Skripsi. Surakarta: Fakultas Psikologi Universitas Muhammadiyah Surakarta.

Nadzir, M. (2015). Psychological meaning of money dengan gaya hidup hedonis remaja di kota Malang. Skripsi. Malang: Fakultas Psikologi Universitas Muhammadiyah Malang.

Oley, P.C. (2012). Perilaku politik aktivis mahasiswa fakultas ilmu sosial dan ilmu politik universitas sam ratulangi (Suatu studi terhadap pengurus organisasi mahasiswa fakultas ilmu sosial dan ilmu politik universitas sam ratulangi tahun 2012). Skripsi. Denpasar: Fakultas Ilmu Sosial dan Ilmu Politik Universitas Sam Ratulangi.

Paramitha, R.D. (2015). Hubungan motif afiliasi dengan sikap korupsi pada mahasiswa. Skripsi. Malang: Fakultas Psikologi Universitas Muhammadiyah Malang.

Purworini, D. (2003). Terpaan sinetron, ABG, teman pergaulan, uang saku dan gaya hidup hedonism. Skripsi. Surakarta: Fakultas Ilmu Sosial dan Ilmu Politik Universitas Negeri Surakarta.

Puspitasari, Y.R., Haryadi, B., \& Setiawan, A.R. (2015). Sisi remang pengelolaan keuangan organisasi mahasiswa. Jurnal Akuntansi Multiparadigma, 6(1), 133144.

Rabl, T. (2011). The impact of situational influences on corruption in organizations. Journal of Business Ethics, 100, 85-101.

Rianton. (2013). Hubungan antara konformitas kelompok teman sebaya dengan gaya hidup hedonis pada mahasiswa kab. Dhamasraya di Yogyakarta. Jurnal Publikasi. Yogyakarta: Fakultas Psikologi Universitas Ahmad Dahlan.

Rokhmah, S.N. (2016). Pengaruh role model dan religiusitas terhadap perilaku antikorupsi pada mahasiswa organisatoris di Malang. Skripsi. Malang: Fakultas Psikologi Universitas Muhammadiyah Malang. 
Rosandi, F. (2004). Perbedaan perilaku konsumtif antara mahasiswa pria dan wanita di Universitas Katolik Atma Jaya. Skripsi. Yogyakarta: Universitas Katolik Atma Jaya.

Rosdiana, A. (2011). Faktor-faktor psikologis yang mempengaruhi intensi merokok pada remaja. Skripsi. Jakarta: Fakultas Psikologi Universitas Islam Negeri Syarif Hidayatullah.

Sandi, M.R.A. (2015). Peran sosialisasi politik organisasi kemahasiswaan dalam meningkatkan partisipasi politik mahasiswa. Skripsi. Bandung: Fakultas Ilmu Sosial dan Ilmu Politik Universitas Pendidikan Indonesia.

Santrock, J.W. (2008). Adolscence. Ed 12. New York: McGraw-Hill Companies.

Setyaningsih, S. (2013). Perilaku konsumtif berdasarkan faktor demografi dan money attitude studi pada mahasiswa FEB UKSW. Skripsi. Salatiga: Fakultas Ekonomi \& Bisnis Universitas Kristen Satya Wacana.

Sugiyono. (2014). Metode penelitian kuantitatif kualitatif dan $R \& B$. Bandung: Alfabeta.

Tim Pansus Lokakarya REMA UPI. (2016). Bentuk ormawa UPI dan eksistensi ormawa tingkat fakultas. Naskah Pubilkasi. Bandung: Universitas Pendidikan Indonesia.

Trimartati, N. (2014). Studi kasus gaya hidup hedonism mahasiswa bimbingan dan konseling Universitas Ahmad Dahlan. Jurnal Psikopedagogi, 3(1).

Umami, A. (2013). Hubungan antara harga diri dengan kecenderungan gaya hidup hedonis pada mahasiswa di Surakarta. Skripsi. Surakarta: Fakultas Psikologi Universitas Muhammadiyah Surakarta.

Ulfah, T.A. (2013). Gaya hidup hedonis pada mahasiswa yang mengunjungi tempat hiburan malam ditinjau dari motif afiliasi. Skripsi. Semarang: Fakultas Psikologi Universitas Semarang.

Wahyuni, Z.I., Andriani, Y., \& Nihayah, Z. (2015). The relationship between religious orientation, moral integrity, organizational climate and anti corruption intention in Indonesia. International Journal of Social Science and Humanity, 5(10).

Walida, H.A. (2015). Hubungan religiusitas dengan sikap terhadap korupsi pada mahasiswa. Skripsi. Malang: Fakultas Psikologi Universitas Muhammadiyah Malang.

Weijers, D.M. (2012). Hedonism and happiness in theory and practice. Thesis. Victoria University of Wellington.

Zulkifli, A. R. (2016). Gaya hidup hedonisme di kalangan mahasiswa penerima beasiswa Kaltim cemerlang 2014 di fakultas ilmu sosial dan ilmu politik universitas mulawarman. eJournal Sosiatri-Sosiologi, 4(1), 72-85. 